\title{
PENDIDIKAN DAN PENGAKUAN HUKUM PENYANDANG DISABILITAS DI INDONESIA
}

\author{
Oleh: M. Jamil ${ }^{1}$
}

Negara Indonesia adalah negara hukum, begitu bunyi Pasal 1 Ayat (3) amandemen ketiga Undang-Undang Dasar Negara Republik Indonesia Tahun 1945 (UUD 1945). Karena Negara Kesatuan Republik Indonesia (NKRI) menganut Negara hukum, maka dalam suatu negara hukum semua orang harus diperlakukan sama dihadapan hukum (equality before the law). Pemberlakuan sama dihadapan hukum tersebut, baik dalam kesehariannya sebagai masyarakat Indonesia maupun dalam penerimaan haknya dalam hal pendidikan, baik fisiknya sehat secara jasmani dan rohati maupun keterbelakangan mental (penyandang disabilitas).

Pasal 28H Ayat (2) amandemen kedua UUD 1945 mengatakan bahwa "setiap orang berhak mendapat kemudahan dan perlakuan khusus untuk memperoleh kesempatan dan manfaat yang sama guna mencapai persamaan dan keadilan.”

Negara Kesatuan Republik Indonesia (NKRI) melaksanakan pembangunan nasional di segala bidang kehidupan dengan tujuan dasar untuk melindungi dan memajukan kesejahteraan umum, mencerdaskan kehidupan bangsa serta ikut melaksanakan ketertiban dunia. Bangsa Indonesia terdiri dari jutaan penduduk yang hidup bermasyarakat dan mempunyai latar belakang berbeda. Dalam kehidupan bermasyarakat, setiap warga Negara Indonesia mempunyai hak dan kewajiban yang sama untuk mewujudkan cita-cita dan tujuan dasar pembangunan nasional. Hak dan kewajiban yang sama tersebut tidak terkecuali pada masyarakat Indonesia penyandang disabilitas.

1 Ketua Umum Pusat Studi Mahasiswa Pascasarjana (PUSMAJA) Mbojo-Yogyakarta Periode 2015-2017 || Ketua II Bagian Eksternal Dewan Pimpinan Cabang Perhimpunan Mahasiswa Hukum Indonesia Daerah Istimewa Yogyakarta (DPC PERMAHI DIY) Periode 2012-2014 | Email: jamilncera@gmail.com |FB/Youtube/IG/Twitter: @MJAMILSH | Website: http://www.mjamil.my.id. 
Masyarakat Indonesia memiliki hak berpendidikan yang layak serta diakui secara hukum begitu juga penyandang disabilitas. Untuk memperkuat pengakuan penyandang disabilitas, maka pada tanggal 15 April 2016 Presiden Republik Indonesia Joko Widodo mengesahkan Undang-Undang Republik Indonesia Nomor 8 Tahun 2016 Tentang Penyandang Disabilitas (UU Penyandang Disabilitas). Disimpan dalam Lembaran Negara Republik Indonesia Tahun 2016 Nomor 69, serta Tambahan Lembaran Negara Republik Indonesia Nomor 5871.

Sebelum membahas lebih jauh tentang pendidikan dan pengakuan hukum penyandang disabilitas, alangkah baiknyakita terlebih dulu mengetahui apa itu penyandang disabilitas. Bila melirik dalam Pasal 1 Ayat (1) Undang-Undang Republik Indonesia Nomor 8 Tahun 2016 Tentang Penyandang Disabilitas, disebutkan bahwa "Penyandang Disabilitas adalah setiap orang yang mengalami keterbatasan fisik, intelektual, mental, dan/atau sensorik dalam jangka waktu lama yang dalam berinteraksi dengan lingkungan dapat mengalami hambatan dan kesulitan untuk berpartisipasi secara penuh dan efektif dengan warga negara lainnya berdasarkan kesamaan hak”. Sedangkan dalam Pasal 1 Angka 1 Undang-Undang Nomor 4 Tahun 1997 tentang Penyandang Cacat, menjelaskan bahwa "Penyandang cacat adalah setiap orang yang mempunyai kelainan fisik dan/atau mental, yang dapat mengganggu atau merupakan rintangan dan hambatan baginya untuk melakukan secara selayaknya, yang terdiri dari: a. penyandang cacat fisik; b. penyandang cacat mental; c. penyandang cacat fisik dan mental."

Adanya pengaturan mengenai pemenuhan hak-hak penyandang disabilitas harus mencakup perlindungan terhadap hak asasi penyandang disabilitas yang sama dan setara dengan hak asasi manusia pada umumnya, tanpa memandang sebelah mata mengenai ada atau tidaknya kecacatan secara fisik atau kecacatan mental.

\section{Pengakuan Hukum Penyandang Disabilitas di Indonesia}

Sebelum pengesahan UU Penyandang Disabilitas, sebenarnya jauh-jauh waktu sudah ada peraturan perundang-undangan sebagai upaya untuk melindungi, 
menghormati, memajukan, dan memenuhi hak-hak penyandang disabilitas, diantaranya: Undang-Undang Nomor 4 Tahun 1997 tentang Penyandang Cacat serta Undang-Undang Nomor 19 Tahun 2011 tentang Pengesahan Convention on The Rights of Persons with Disabilities (Konvensi Mengenai Hak-Hak Penyandang Disabilitas) yang ditetapkan oleh Pemerintah pada tanggal 10 November 2011, dimana konvensi internasional tersebut telah ditandatangani oleh Pemerintah Indonesia sejak tanggal 30 Maret 2007 di New York.; Undang-Undang Nomor 39 Tahun 1999 tentang Hak Asasi Manusia; Undang-Undang Nomor 23 Tahun 2002 tentang Perlindungan Anak; Undang-Undang Nomor 28 Tahun 2002 tentang Bangunan Gedung; Undang-Undang Nomor 13 Tahun 2003 tentang Ketenagakerjaan; Undang-Undang Nomor 20 Tahun 2003 tentang Sistem Pendidikan Nasional; Undang-Undang Nomor 3 Tahun 2005 tentang Sistem Keolahragaan Nasional; Undang-Undang Nomor 23 Tahun 2007 tentang Perkeretaapian; UndangUndang Nomor 17 Tahun 2008 tentang Pelayaran; Undang-Undang Nomor 1 Tahun 2009 tentang Penerbangan; Undang-Undang Nomor 11 Tahun 2009 tentang Kesejahteraan Sosial; Undang-Undang Nomor 22 Tahun 2009 tentang Lalu Lintas dan Angkutan Jalan; Undang-Undang Nomor 25 Tahun 2009 tentang Pelayanan Publik; Undang-Undang Nomor 36 Tahun 2009 tentang Kesehatan; dan UndangUndang Nomor 13 Tahun 2011 tentang Penanganan Fakir Miskin. Selain undangundang, terdapat juga dalam peraturan daerah, seperti yang dilakukan oleh pemerintah Daerah Istimewa Yogyakarta yang termaktub dalam Peraturan Daerah Nomor 4 Tahun 2012 tentang Perlindungan dan Pemenuhan Hak-Hak Penyandang Disabilitas.

Negara yang bermartabat adalah Negara yang menghormati, menghargai, memenuhi dan memberikan perlindungan bagi setiap warga negaranya tanpa kecuali. Isu tentang penyandang disabilitas atau orang-orang yang memiliki perbedaan kemampuan seringkali dikenal dengan istilah "difable" (differently abled people) atau sekarang dikenal sebagai "disabilitas" adalah masalah yang paling jarang mendapatkan perhatian dari Pemerintah maupun masyarakat. Negara Republik 
Indonesia adalah Negara yang berdasarkan Pancasila dan Undang-Undang Dasar Negara Republik Indonesia Tahun 1945 yang menghormati dan menjunjung tinggi harkat dan martabat manusia sehingga perlindungan dan pemajuan hak asasi manusia terhadap kelompok rentan khususnya penyandang disabilitas perlu ditingkatkan. Hal ini terlihat dalam Pasal 5 ayat (1), Pasal 11, Pasal 20, dan Pasal 28 I ayat (2) UndangUndang Dasar Negara Republik Indonesia Tahun 1945. [Rahayu Repindowaty Harahap dan Bustanuddin, "Perlindungan Hukum Terhadap Penyandang Disabilitas Menurut Convention On The Rights Of Persons With Disabilities (CRPD)", Jurnal Inovatif, Volume VIII Nomor I Januari 2015]

\section{Hak-Hak Penyandang Disabilitas}

Pada Pasal 5 Ayat (1) Undang-Undang Republik Indonesia Nomor 8 Tahun 2016 Tentang Penyandang Disabilitas, menyubutkan bahwa Penyandang Disabilitas memiliki hak sebagai berikut: a. hidup; b. bebas dari stigma; c. privasi; d. keadilan dan perlindungan hukum; e. pendidikan; f. pekerjaan, kewirausahaan, dan koperasi; g. kesehatan; h. politik; i. keagamaan; j. keolahragaan; k. kebudayaan dan pariwisata; 1. kesejahteraan sosial; m. Aksesibilitas; n. Pelayanan Publik; o. Pelindungan dari bencana; p. habilitasi dan rehabilitasi; q. Konsesi; r. pendataan; s. hidup secara mandiri dan dilibatkan dalam masyarakat; dan t. berekspresi.

Dengan hadirnya UU Penyandang Disabilitas, seharusnya kita mengapresiasinya, dengan ini, pemerintah tidak ada lagi alasan pemerintah untuk tidak melindungi hak-hak penyandang disabilitas, karena hak-hak mereka sudah mendarah daging dalam ruh aturan perundang-undangan yang legal formal pemberlakuannya di Indonesia. Mengabaikan hak-hak penyandang disabilitas berarti mengabaikan undang-undang, mengabaikan undang-undang berarti mengabaikan harga dirinya sebagai pembuat dan pelaksana undang-undang.

Selain berharap pada pemerintah sebagai pelaksana undang-undang, semua pihak (stake holder) juga tidak tinggal diam, harus bahu membahu dalam upaya 
mengangkat harkat dan martabat para penyandang disabilitas di Indonesia dengan cara dan kadar kemampuan yang dimiliki.

\section{Pendidikan bagi Penyandang Disabilitas}

Perhatian orang terhadap penyandang disabilitas mulai banyak, baik itu dalam bentuk riil pendampingan maupun supporting dalam bentuk menyuarakan dalam tulisan, salahsatu yang penulis baca adalah tulisan Akhmad Soleh dengan judul "Kebijakan Perguruan Tinggi Negeri Yogyakarta terhadap Penyandang Disabilitas" yang dimuat dalam Jurnal Pendidikan Islam, Volume IIII, Nomor 1, Juni 2014/1435. Ahmad Soleh dalam tulisannya tersebut memaparkan tiga pola dalam menangani pendidikan bagi penyandang disabilitas yang selama ini dilakukan oleh lembaga pendidikan di Indonesia, diantaranya adalah sebagai berikut:

\section{Sekolah Luar Biasa (Segregasi)}

Sekolah luar biasa (special school) adalah pendidikan yang menyediakan desain/setting khusus, seperti kelas khusus, sekolah khusus, dan sekolah atau lembaga khusus dengan model diasramakan. Sekolah ini sering kali hanya ditujukan bagi tunanetra, tunarungu, tunagrahita, dan tunadaksa.

Pendidikan semacam ini tidak selalu memenuhi kebutuhan pendididkan anak karena salah satu kelemahannya adalah pendidikan setting segregasinya, yaitu isolasi dan hilangnya kesempatan berbagi dengan teman sebaya dan belajar satu sama lain tentang perilaku dan keterampilan yang relevan.

Tujuan pendidikan luar biasa secara khusus bertujuan: pertama, agar anak berkelainan memahami kelainan yang dideritanya dan kemudian menerimanya sebagai suatu keadaan yang harus dihadapi. Kedua, agar anak berkelainan menyadari bahwa anak penyandang disabilitas merupakan anggota masyarakat, warga negara dengan hak dan kewajiban yang sama dengan warga negara yang lain. Ketiga, agar anak berkelainan berdasarkan kemampuan yang ada padanya sesuai dengan hak dan kewajibannya berusaha dan berjuang menutup dan mengisi kekurangan yang ada padanya agar menjadi warga negara yang mandiri, tidak bergantung pada bantuan dan 
pertologan orang lain dan pemerintah. Keempat, agar anak berkelainan memiliki pengetahuan dan keterampilan (sesuai dengan kelainannya) sehingga dapat mencari nafkah dengan pengetahuan dan keterampilannya. Kelima, agar anak berkelainan pada akhirnya dapat bergaul dengan masyarakat tanpa perasaan rendah diri dan agar dapat dapat menghargai keagungan Tuhan Yang Maha Esa.

\section{Pendidikan Integrasi}

Pendidikan integrasi adalah integrasi siswa penyandang disabilitas ke dalam taman sekolah reguler dan telah dilakukan selama betahun-tahun dan dengan cara yang bebeda-beda. Anak penyandang disabilitas yang mengikuti kelas atau sekolah khusus (SLB) dipindahkan ke sekolah reguler ketika anak penyandang disabilitas dianggap siap untuk mengikuti suatu kelas di sekolah reguler. Anak penyandang disabilitas sering ditempatkan dalam suatu kelas berdasarkan tingkat keberfungsiannya dan pengetahuannya, bukan menurut usianya.

\section{Pendidikan Inklusif}

Pola pendidikan inklusif mempunyai pengertian yang beragam. Stainback mengemukakan bahwa sekolah inklusif adalah sekolah yang menampung semua siswa di kelas yang sama. Sekolah ini menyediakan program pendidikan yang layak, menantang, tetapi sesuai dengan kemampuan dan kebutuhan setiap siswa. Lebih dari itu, sekolah inklusif juga merupakan tempat setiap anak dapat diterima, menjadi bagian dari kelas tersebut, saling membantu dengan guru dan teman sebayanya, maupun anggota masyarakat lain agar kebutuhan individualnya dapat terpenuhi. Staub dan Peck mengemukakan bahwa pendidikan inklusif adalah penempatan anak yang menunjukkan bahwa kelas reguler merupakan tempat belajar yang relevan bagi anak berkelainan, apa pun jenis kelainannya dan bagaimanapun gradasinya.

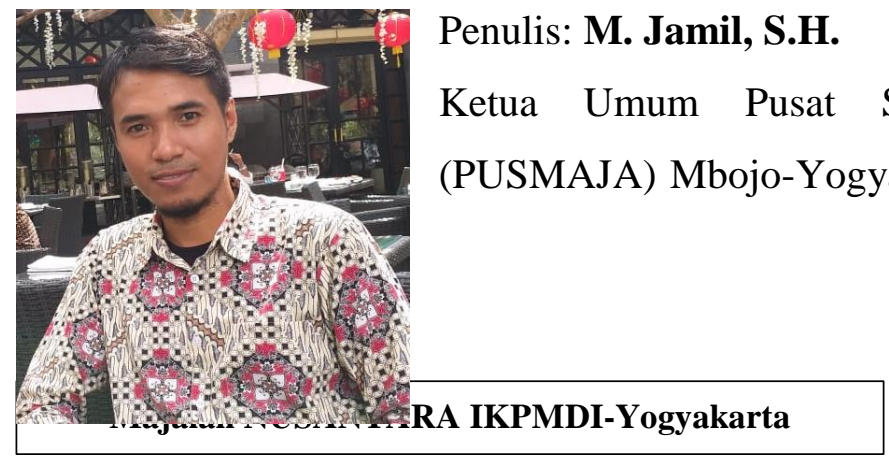


Edisi Juli-Agustus 2016, lihat Halaman 26-28

"Pendidikan dan Pengakuan Hukum Penyandang Disabilitas di Indonesia"

II Bagian Eksternal Dewan Pimpinan Cabang Perhimpunan Mahasiswa Hukum Indonesia Daerah Istimewa Yogyakarta (DPC PERMAHI DIY) Periode 2012-2014

\section{Ful Sumber Tulisan:}

M. Jamil, "Pendidikan dan Pengakuan Hukum Penyandang Disabilitas di Indonesia", Majalah NUSANTARA IKPMDI-Yogyakarta, diterbitkan melalui Dinas Pendidikan Pemuda dan Olahraga (Disdikpora) Daerah Istimewa Yogyakarta, edisi Juli-Agustus 2016, lihat Halaman 26-28. 